ISSN: 2644-1373

\title{
Salisbury, Novichok and the OPCW
}

\author{
Benjamín Ruiz Loyola* \\ Department Of Organic Chemistry, Universidad Nacional Autónoma De México
}

*Corresponding author: Benjamín Ruiz Loyola, Department Of Organic Chemistry, Universidad Nacional Autónoma De México

\begin{abstract}
The poisoning of a former russian spy in Salisbury, England, in march 2018, led to the Discovery of several chemical weapons not included in the Chemical Weapons Convention, allegedly developed by the URSS and not declared by Russia. This, in some way, has made diplomatic pressure to modify the lists of chemicals forbbiden or controle by the CWC, with some reluctancia by the russian government and some of their alias. The Organización for the Prohibition of Chemical Weapons (OPCW) has started actions to include novichok agents in the lists of prohibited agents. This is the story.
\end{abstract}

Keywords: Novichok; Nerve Agents; Poisons; OPCW; Skripal; Salisbury

\section{The Beggining}

In the spring of 2018, Sergei Skripal (former russian spy) and his daughter Yulia, started to feel ill. It was found that they were poisoned with a chemical hard to identify; however, an excellent chemical analysis let the analytical team to say that the chemical(s) employed were some nerve agents that were not included in the control lists establishers in the Chemical Weapons Convention (CWC), however, this compounds are chemical weapons of a new class, never declared by any state party member of the CWC. The scientists arrived at the conclusion that the chemicals employed belong to a group of nerve agents known as Novichok. These chemicals act as acetylcholinesterase inhibitors, same as VX or Sarin, but more tonics (it is said that eight times as poisonous as VX, and with effects as rapid as 30 seconds [1-4].

According to Al Jazeera, Skripal and his daughter were found unconscious on a bench outside a mall in Salisbury on March 4, 2018, poisoned. Skripal is a former Russian military intelligence officer accused of spying for the United Kingdom. He was imprisoned in 2006, and later was part of an exchange program for Russian citizens accused of espionage in the United States. He was granted asylum in the United Kingdom. It is considered that the poisoning was made through the knob of the main door of his house, since that was the place where the highest concentration of nerve agent was found. The first actions of the british government included that 23 undeclared Russian intelligence officers were expelled from the UK. Before the analysis of the evidence gave a confirmation of the agent employed, a police officer who visited the Skripal's home was admited in a hospital with symptoms characteristic with a nerve agent poisoning [5]. In the end, these three victims were capable of recovery. Several weeks later some civilians were found with similar medical condition in Amesbury, a town about $11 \mathrm{~km}$ from Salisbury. Charlie Rowley found a fake Premier Jour (Nina Ricci) parfume bottle that he recovered and gave to his wife, Dawn Sturges'. They assambled the atomizer and she applied the liquid in her wrists. And so, they were contaminated. The bottle contained not parfume but a nerve agent. This case was tested as terrorism by the british authorities [6]. Dawn went into ICU at Salisbury Hospital and died a week later. Charlie survived and was released from the hospital, but several days later he was admitted again with an acute case of meningitis and blindness, and unable to move his left arm. On March 12 Theresa May declared: "Either this was a direct action of the Russian State towards our country, or the russian government lost control over the substance with the potential for catastrophic destruction and allowed it to fall into the hands of others. On april 2018, scientists from the Organization for the Prohibition of Chemical Weapons (OPCW) confirmed the presence of Novichok in biological sampling from the Skripals as well as from the site of the presumed contamination. On september of the same year, a couple of suspects were identified, two russian citizens members of the russian intelligence body (GRU), that flew from Moscow to London just two days prior to the Skripal poisoning and were in Salisbury for only 30 minutes. They were identified as Alexander Mishkin, and Anatoly Chepiga Both were honored for their actions in Ukraine [7]. 


\section{International Reacticos}

This situation led to a series of diplomatic actions from several countries: USA expelled 60 russians from its territorial, including 12 officials from the Russia UN misión; UK made the same with 34 russian diplomats. Other EU countries expelled 34 diplomats, Ukraine did the same with 13 diplomats, the OTAN expelled 7 and other countries around the world added for 13 more expelled diplomats [8,9]. On its side, Russia retaliated by expelling 23 british diplomats and 60 from USA. And something bizarre: the russian government conducted a Twitter poll to let the russian people determine which USA consulate was to be closed. The winner was the St. Peterburg one.

In The 1970 Decade, the Soviets had a Nerve Agents Development Program Known as Folinate, that Intended to have Chemicals that were:

a) Non detected by conventional detection OTAN instrumentos;

b) Capable of penétrate the soldares' body, even with full protecting clothes;

c) Safer to preparation, handling and storage.

By the end of the 1990 decade, the russian government was looking that this chemicals or their precursors were not mentioned by the CWC.

\section{What we know and what we don't:}

Most of what we understood as of 2018 of Novichok agents comes from testimony and memoirs of Dr. Vil S. Mirzayanov, the Chief of the Department of Counteraction against Foreign Technical Intelligence at the Russian State Union Scientific Research Institute for Organic Chemistry and Technology (Gonio) [10]. In 1995, The Stimson Center published a document: Chemical weapons disarmament in Russia: Problems and prospects. 1995, The Stimson Center, consisting of several essays written by various specialists in chemical weapons and in Russia. Particularly, Mirzayanov wrote a paper: Dismantling the Soviet/Russian Chemical Weapons Complex: An Insider's View. This can be read in this paper, Mirzayanov wrote that the soviets in 1978 finished the construction of a large facility for nerve agent's production, with capacity to make 20,000 tons annually, and that they produced 15,000 tons of a chemical called Substance 33, similar to the nerve agent VX. He mentions a group of chemicals with the names A-230, A-232, and the series of chemicals called Novichok, intended to be handled as binary weapons, in response to the US Big Eye project, to produce Sarin in a binary way $[11,12]$. These Novichok chemicals (basically Substance 33, A-230 and A-232, as well as others named Novichok-5, Novichok-7 and a no-name Novichok, tested 1988-19989) were never mentioned in bilateral Memorandums of Understanding designed to promote mutual transparency among URSS/Russia and USA about chemical weapons programs.

Jonathan Tucker informed in 2000, that Russia denied any production of Novichok, but also signed an agreement with the Syria government to create a syrian center for chemical weapons defense, under the cover of a Syrian Center of Ecological Protection, and reports that three russian scientists working in that center were involved on the novichok program; Tucker also says that in 1999 a London based arabic newspaper reported that some Syrian missile warheads were loaded with VX and a novel agent called novichok [13]. So, for as long as 24 years the name novichok has been in the chemical weapons universe, but for over 20 of those years it was some kind of urban legend, untill 2018 when it surfaced publicly and with a lot of noise [14]. We now know that it is another chemical that interferes with the metabolism of the neuro transmitter acetylcholine, binding to the acetylcholinesterase enzyme, and that can result in death. And a recent technical report informs that it is much more toxic than VX because novichok (in a theoretical computer simulation) has fewer conformers than VX; while VX shows 6561 conformers, the novichok A-234 shows 486 and A-230 shows only 54 , which leads to a faster binding among the neurotoxic agent and the acetylcholinesterase enzyme that governs the metabolic transformation of acetylcholinesterase.

\section{Novichok and the OPCW}

In the sixteenth session of the Scientific Advisory Board (SAB) of the OPCW, 4-6 April 2011, on the agenda item elevenNovel toxic compounds, two of the points discussed were related to novichok. I will reproduce them completelly, according to the published report. 11.1 The Chairperson introduced the topic of new toxic compounds that are not included in the schedules of chemicals. This has been attracting increasing attention in recent years, particularly among non-governmental organizations (NGOs). Although very little information has appeared in the public domain, there have been claims that a new class of nerve agents, known as "Novichoks", has been developed. In December 2008, a former defence scientist published a book, which included information on structures reported to be those of the new agents. Some of these structures meet the criteria for Schedule 2 B4 (S2 B4); however, all others are non-scheduled chemicals [15]. The author claimed that the toxicity of certain "Novichok" agents may exceed that of VX. 11.2 In a discussion of the issue, SAB members emphasised that, to date, there has been no confirmation of the author's claims, nor has any peer review been undertaken in regard to the information on these chemicals in the scientific literature on this subject. The SAB noted that those chemicals containing a phosphorus atom to which is bonded one methyl, ethyl or propyl (normal or iso) group but not further carbon atoms would be declarable as S2 B4 chemicals above a threshold of one tone [11]. The SAB asked the Secretariat if such chemicals had ever been declared. The Secretariat replied that it has no record of any such declarations. With respect to nonscheduled chemicals relevant to "Novichoks", it was noted that for declarations under the other chemical production facility (OCPF) regime, the name of the chemical is not required, and therefore, the Secretariat would not be able to determine (from declarations received) if there are facilities producing "Novichok" agents that are also non-scheduled chemicals. So, as can be seen, the OPCW had an early information, but the internal procedures stablished by the CWC did not permit the organization to go further. However, the SAB understood that it was a serious danger and started working 
in two areas intended to prevent the resurgement of the chemical weapons, that is, education and outreach.

Because the Salisbury incident, the OPCW made an investigation and concluded (12 april 2018) that it was a toxic agent the chemical employed against Skripal and his daughter, that the identity of this toxic chemical coincided with the one obtained in UK analysis, and that it was of high purity. The name and stucture of the identified toxic chemical are contained in a classified report of the Technical Secretariat of the OPCW, available only to CWC States Parties. On 2 May 2018, the OPCW Director General made a request for information from States Parties on new types of nerve agents, supported by the 12 april report; in the same date, the Director General made an equal request from the SAB [16]. Later, on 4 september 2018, a report from the OPCW Technical Secretariat the findings were that the analysis of a simple of the small bottle found by Charles Rowley and Dawn Sturgess showed that the simple consisted of the same toxic chemical found in the Skripal's simple, with a concentration of $97-98 \%$. Once again, the name and chemical structure of the toxic chemicals identified are contained in the full confidential report that the Technocal Secretariat of the OPCW made available to all State Parties. The Russian position was that, since novichok was not listed in the prohibited substances, there was no violation of the CWC.

On october 2018, Russia's military intelligence service (GRU) was accused of a hacking intent against OPCW headquarters, which led to four russians being expelled from The Netherlands after this alleged cyber strike. This came after UK government accused the GRU of some other cyber-attacks across the whole globe. A proposal made jointly by Canada, The Netherlands and the United States was revised in a OPCW Executive Council and in January of 2019 was adopted by the council, so was informed by Sabine Nolde, Canada's representative, and confirmed the Dutch foreign ministry. This opened a 90 days period to object or make observations to this adopted proposal. In april of 2019 it was expected that the majority of the OPCW members would vote supporting the addition of novichok in the annex of the CWC forbidding some substances.

\section{Conclusion}

This kind of poisoning actions by Russia is not new, just remember the Alexander Litvinenko's murder. This whole case shows that no matter the compromise of an international agreement to ban weapons of mass destruction, there will always be rogué states or groups of non-state actors willing to produce and use them; so, the OPCW must be fiercely supported by all nations and all people concerned with global peace and understanding.

\section{References}

1. Peter R Chai, Bryan D Hayes, Timothy B Erickson, Edward W Boyer (2018) Novichok agents: a historical, current, and toxicological perspective. Toxicology Communications 2(1): 45-48.

2. Novichok victim found substance disguised as perfume in sealed box.

3. Novichok: Murder inquiry after Dawn Sturgess dies-BBC.

4. Philip Whiteside, Amesbury novichok was same as poisoned Skripals OPCW, Skynews.

5. Jonathan B Tucker, Kathleen M Vogel (2000) Preventing the Proliferation of Chemical and Biological Weapon Materials and Know-How. The Nonproliferation Review/Spring, p. 88-96.

6. Robson Fernandes de Farias (2019) The number of conformers explain the high toxicity of novichok agents. The Pharmaceutical and Chemical Journal 6(1): 24-26.

7. Report of the Scientific Advisory Board of the OPCW.

8. (2018) Note by the Technical Secretariat, Summary of the report on activities carried out in support of a request for technical assistance by the United Kindom of Great Britain and Northern Ireland (Technical Assistance Visit TAV/02/18, S/1612/2018, 12 april 2018). OPCW.

9. (2018) Request for information from States Parties on new types of nerve agents. Note by the Director General OPCW, p. 1-4.

10. (2018) Note by the Technical Secretariat, Summary of the report on activities carried out in support of a request for technical assistance by the United Kindom of Great Britain and Northern Ireland (Technical Assistance Visit TAV/02/18, S/1612/2018, 12 april 2018), OPCW.

11. Hay Alastair (2018) Nerve Agent: Who controls the world's most toxic chemicals? BBC.

12. Novichok used in spy poisoning, chemical weapons watchdog confirms.

13. Hay Alastair (2018) Novichok: Why nerve agent stays deadly for so longBBC News.

14. Russian spies tried to hack chemicals watchdog probing Novichok attack.

15. (2019) OPCW to add Novichok nerve agent to banned substance list. The Defense Post.

16. (2019) OPCW members to support adding Novichok to chemical weapons list-Dutch top diplomat. Tass russian news agency.

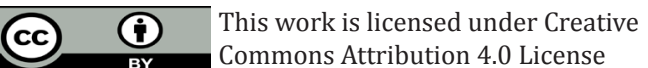

To Submit Your Article Click Here: Submit Article

DOI: 10.32474/LOJPCR.2019.01.000118

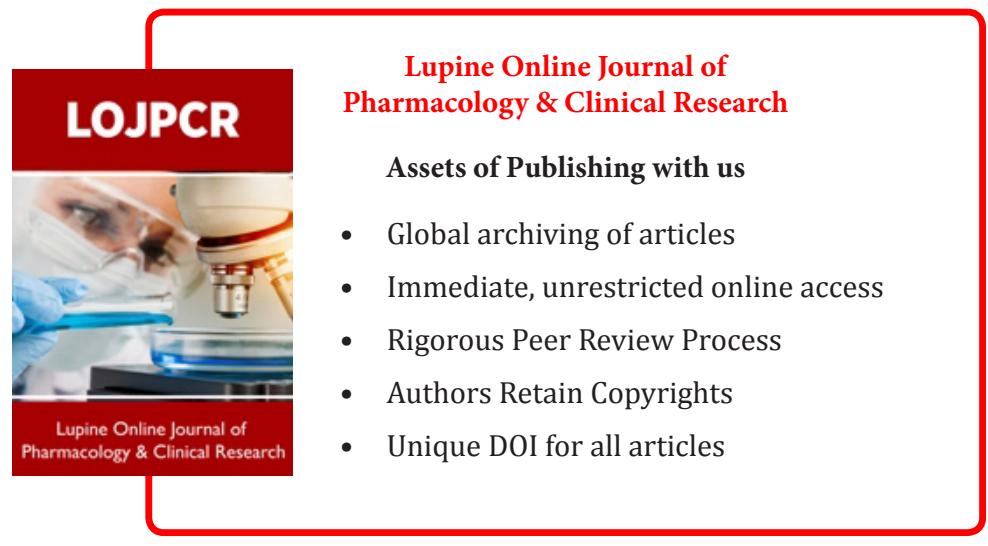

